\title{
Publisher Correction: Multiobjective differential evolution-based multifactor dimensionality reduction for detecting gene-gene interactions
}

\author{
Cheng-Hong Yang ${ }^{1,2}$, Li-Yeh Chuang ${ }^{3} \&$ Yu-Da Lin ${ }^{1}$
}

Scientific Reports 7:12869; doi:10.1038/s41598-017-12773-x; Article published online 09 October 2017

The original HTML version of this Article contained an error in the footnote of Table 2.

"a Chr chromosome; ${ }^{\mathrm{b} M O D E M D R}$ running time; time unit: comment = "Style change has been done. Please check. "hour (h); **optimal epistatic interaction; *top ten epistatic interactions".

now reads:

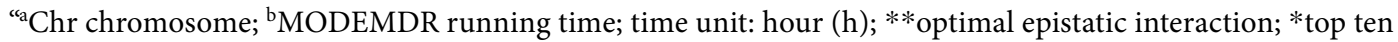
epistatic interactions".

This error has now been corrected in the HTML version of the Article; the PDF version was correct from the time of publication.

(i) Open Access This article is licensed under a Creative Commons Attribution 4.0 International cc) License, which permits use, sharing, adaptation, distribution and reproduction in any medium or format, as long as you give appropriate credit to the original author(s) and the source, provide a link to the Creative Commons license, and indicate if changes were made. The images or other third party material in this article are included in the article's Creative Commons license, unless indicated otherwise in a credit line to the material. If material is not included in the article's Creative Commons license and your intended use is not permitted by statutory regulation or exceeds the permitted use, you will need to obtain permission directly from the copyright holder. To view a copy of this license, visit http://creativecommons.org/licenses/by/4.0/.

(C) The Author(s) 2017

\footnotetext{
${ }^{1}$ Department of Electronic Engineering, National Kaohsiung University of Applied Sciences, Kaohsiung, 80778, Taiwan. ${ }^{2}$ Graduate Institute of Clinical Medicine, Kaohsiung Medical University, Kaohsiung, 80708, Taiwan. ${ }^{3}$ Department of Chemical Engineering and Institute of Biotechnology and Chemical Engineering, I-Shou University, Kaohsiung, 84004, Taiwan. Li-Yeh Chuang and Yu-Da Lin contributed equally to this work. Correspondence and requests for materials should be addressed to L.-Y.C. (email: chuang@isu.edu.tw) orY.-D.L. (email: e0955767257@ yahoo.com.tw)
} 